\title{
Eight to thirteen years old children fear at dental treatment
}

\author{
Dwi Destaria Aryani*, Meirina Gartika*, Syarief Hidayat* \\ *Departement of Pedodontics Faculty of Dentistry Universitas Padjadjaran
}

\section{ABSTRACT}

Introduction: Fear is an emotion occurring in situation of stress and uncertainty and can make the person experience the threatened or helpless feeling. The etiology of child dental fear consist of personal factor, external factor, and dental factor. The purpose of this study was to describe the child fear at 8-13 years of age toward dental treatment and find the most dominant etiology of fear. Methods: A descriptive survey was conducted amongs 53 childs in MI Cikapayang Islamic Elementary School who had ever gotten the dental treatment using CFSS-DS and questionnaire. The sampling method was total sampling. Results: The result shows that the description of child fear at 8-13 years of age to the dental treatment is not afraid at all $(45,3 \%)$, a little afraid $(33 \%)$, a fair amount afraid $(15,2 \%)$, pretty much afraid (4\%), and the most little is very afraid $(2,5 \%)$. The etiology of child dental fear consist of personal factor $(52,8 \%)$, external factor $(7,5 \%)$, and dental factor $(39,6 \%)$. Conclusion: Majority of child fear at 8-13 years of age to the dental treatment in MI Cikapayang Islamic Elementary School feel not afraid at all to the dental treatment $(45,3 \%)$ and the most dominant etiology is personal factor $(52,8 \%)$.

Keywords: Child fear, dental treatment, etiology.

\section{INTRODUCTION}

The success of a dental treatment in children besides specified on the clinical knowledge and skills of the dentist, also determined by the child's ability to cooperate during treatment. Therefore, a dentist needs to have a basic knowledge about the management of children not only on the issue of clinical care, but also psychological and child behavioral. ${ }^{1}$

One of the obstacles often faced by a dentist is the attitude of children who are less cooperative because of their fear for dental treatment. The fear of children is not an abnormal thing because instinctively these feeling it will evolve in the process of child development.
These feelings may arise when a child faced with an unpleasant situation or foreigners who would instinctively avoid in an attempt to protect himself from any danger. ${ }^{2}$ Fear can be caused by three factors; personal factors, such as age, gender, and temperament, external factors, such as the environment, parents, peers, and dental factors, such as a less pleasant experience during dental care, dentists' attitude are not good, and the pain inflicted during dental treatment. ${ }^{3}$

Based on the results of a survey conducted by Todd and Walker in 1980 to $6000,58 \%$ of respondents said that the reason of delayed dental care is because of fear of the dentist. ${ }^{4}$ In addition, there are other studies conducted Locker and Lindell in 1997 in Toronto to the 1420 vote, as much as $16.4 \%$ have a fear of dental treatment 
and from these results as much as $50.9 \%$ appears in children, $22 \%$ in young adults, and $27.1 \%$ in adults. ${ }^{5}$ Till this moment, an estimated $6-15 \%$ of the population has a fear of the dentist who tinggi.6 Pediatric patients with fear of unruly and treated so that it can be the cause of $75 \%$ failure routine maintenance. The fear that is not recognized or cannot be solved on the first visit to the dentist can be increased in line with dental care done and will persist until the child becomes dewasa. ${ }^{1}$ Therefore, this study aimed to observe picture frightened children aged 8-13 years Islamic primary school Cikapayang MI against the dentist and find the cause of the most dominant fear.

\section{METHODS}

The research is descriptive by using survey techniques. The sample was 53 students MI Cikapayang Islamic Elementary School aged 8-13 years and never get dental care such as the lifting of the injection and filling with drilled. The method used is total sampling. Equipment and materials used in this study in the form of stationery, CFSSDS, and questionnaires.

The fear of children is measured using CFSSDS. CFSS-DS is one measure of fear in children, consisting of 15 questions that cover different aspects of the situation of dental care and have a 5 -scale assessment of the level of fear, which is not afraid at all, not afraid, a little scared, scared, and very afraid. CFSS-DS has the high reliability, stable, and is designed to be filled children who have gained previous dental treatment. The total value derived from this method ranged from 15 75. A score of 38 or more is indicated by a fear of dental treatment. Etiology dominant fear was measured by using a questionnaire consisting of 12 questions relating to each etiology of fear with a choice of yes and no answers. Based Guttman scale, yes answer is worth one and the answer is not zero. Respondents to the overall etiology and any accumulated actual score obtained compared with the ideal score and compared among the three factors giving rise to a dominant factor which becomes the biggest factor affecting children's fears.

\section{RESULTS}

Research shows a picture of the fear of children aged 8-13 years against dental treatment carried out in MI Cikapayang Islamic Elementary School in May 2012 using the CFSS-DS and questionnaires. The respondent amounted to 53 children aged 8-13 years and never get good dental care repeal by injecting and filling with drilled.

Results of research regarding our fear of children aged 8-13 years against dental care described in the table as in Table 1. The table

Table 1. Overview of Fear Elementary School Children Against Dental Care

\begin{tabular}{|c|c|c|c|c|c|c|c|c|c|c|c|}
\hline \multirow{2}{*}{ No } & \multirow{2}{*}{ Description } & \multicolumn{2}{|l|}{ STT } & \multicolumn{2}{|c|}{ TT } & \multicolumn{2}{|r|}{ AT } & \multicolumn{2}{|c|}{ Fear } & \multicolumn{2}{|r|}{ ST } \\
\hline & & $\mathrm{F}$ & $\%$ & $f$ & $\%$ & $f$ & $\%$ & $f$ & $\%$ & $f$ & $\%$ \\
\hline 1 & Dentist & 34 & 64,2 & 15 & 28,3 & 4 & 7,5 & 0 & 0,0 & 0 & 0,0 \\
\hline 2 & Doctor & 34 & 64,2 & 15 & 28,3 & 1 & 1,9 & 3 & 5,7 & 0 & 0,0 \\
\hline 3 & Syringe & 11 & 20,8 & 22 & 41,5 & 15 & 28,3 & 1 & 1,9 & 4 & 7,5 \\
\hline 4 & Someone checks your teeth & 32 & 60,4 & 12 & 22,6 & 7 & 13,2 & 2 & 3,8 & 0 & 0,0 \\
\hline 5 & Open the mouth & 24 & 45,3 & 20 & 37,7 & 4 & 7,5 & 4 & 7,5 & 1 & 1,9 \\
\hline 6 & Touch by someone & 18 & 34,0 & 20 & 37,7 & 14 & 26,4 & 0 & 0,0 & 1 & 1,9 \\
\hline 7 & Seen by someone & 22 & 41,5 & 19 & 35,8 & 6 & 11,3 & 4 & 7,5 & 2 & 3,8 \\
\hline 8 & Dentist that burs your teeth & 15 & 28,3 & 19 & 35,8 & 14 & 26,4 & 3 & 5,7 & 2 & 3,8 \\
\hline 9 & See the dentist while burring teeth & 27 & 50,9 & 16 & 30,2 & 8 & 15,1 & 2 & 3,8 & 0 & 0,0 \\
\hline 10 & Hearing the bur sound & 23 & 43,4 & 14 & 26,4 & 11 & 20,8 & 3 & 5,7 & 2 & 3,8 \\
\hline 11 & Putting instrument inside the mouth & 23 & 43,4 & 20 & 37,7 & 7 & 13,2 & 2 & 3,8 & 1 & 1,9 \\
\hline 12 & Chocking & 5 & 9,4 & 28 & 52,8 & 17 & 32,1 & 1 & 1,9 & 2 & 3,8 \\
\hline 13 & Visit to the hospital & 29 & 54,7 & 16 & 30,2 & 5 & 9,4 & 3 & 5,7 & 0 & 0,0 \\
\hline 14 & A person dressed in white & 33 & 62,3 & 12 & 22,6 & 5 & 9,4 & 1 & 1,9 & 2 & 3,8 \\
\hline 15 & Nurse cleaning the teeth & 30 & 56,6 & 14 & 26,4 & 3 & 5,7 & 3 & 5,7 & 3 & 5,7 \\
\hline
\end{tabular}




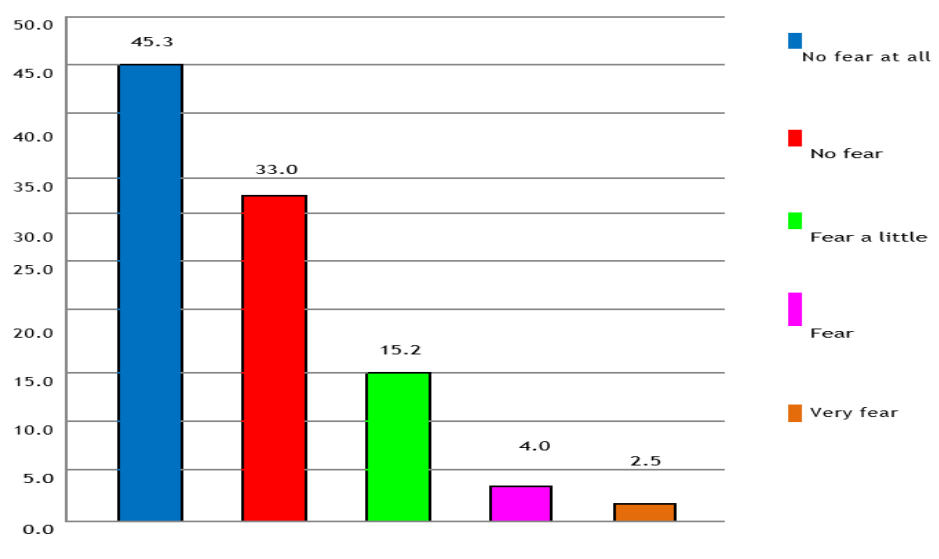

Figure 1. Overview Fear of 8-13 year old of dental care general

\section{Etiology of dominant fears}

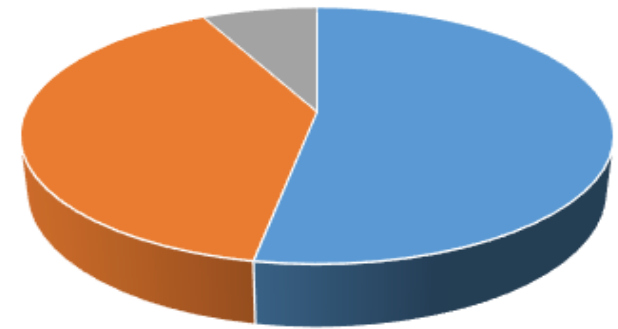

- faktor personal " faktor dental " faktor eksternal

Figure 2. Etiology of dominant fears at dental treatment in 8-13 years-old children

shows that the largest percentage of 15 variables CFSS-DS with a very high level of fear contained in the syringe, which is about $7,5 \%$.

Figure 1 shows that most children Cikapayang Islamic MI Elementary School no fear of dental treatment especially to the treatment procedure which is non-invasive.

Figure 2 shows that dental experience was less pleasant and the pain caused when drilled, injected, or when th tooth get extracted were incorporated into dental factors, and the second largest etiology that can affect children's fear.

\section{DISCUSSION}

Sutadi in 1992 in Semarang conducted a study of 200 respondents and the results $60 \%$ of respondents are afraid of needle insertion suntik. ${ }^{7}$ Kleinknecht in 1973 also stated that the most feared stimulus during dental treatment is viewed syringe and pain caused by the insertion suntik. 8 needle also seen in Table 1 , the percentage of high levels of fear are at variable open your mouth and be seen by others as many as $7.5 \%$, the level of fear is there when choke as much as $32.1 \%$, a low level of fear is also there when choke as much as $52.8 \%$, and very low levels of fear there is at variable see doctors and dentists as many as $64.2 \%$.

Locker and Liddell states that there is a fear of dental treatment relationship with a negative experience either because of pain NSV invasive treatments. Therefore, dental procedures that are invasive to induce fear dental care while the child is non-invasive generally does not cause taste takut. ${ }^{5}$

The etiology which mostly affect the child's fear of dental treatments derived from personal factors, such as the child's temperament. Klingberg 1998 states that children who are shy or are likely to have negative emotions during dental treatment is very risky to have a great fear of the treatment gigi. ${ }^{10}$ External factors, such as parents, peers, and the environment is not 
unduly influence the child's fear. This can occur because of environmental MI Cikapayang often get education about oral and dental problems so that knowledge and awareness of children to take care of teeth is good enough.

\section{CONCLUSION}

Majority of children aged 8-13 years in MI Cikapayang Islamic Elementary School feel very fearful of dental care $(45.3 \%)$ and the most dominant etiology comes from personal factors (52.8\%).

\section{REFERENCES}

1. R Marsitahapsari BN, Supartinah AL, Emut L. 2009. Pengelolaan rasa cemas dengan metode modeling pada pencabutan gigi anak perempuan menggunakan anestesi topikal. J Ked Gi. 2009;1(1):1-6.

2. Sur H, Hayran O, Yildirim C, Mumcu G. Patient satisfaction in dental outpatient clinics in
Turkey. Croatian Med J. 2004. p. 651.

3. Soemartono $\mathrm{SH}$. Penanggulangan anak takut dalam perawatan gigi. JKGUI. 2003;10(1):3540.

4. Koch G, Poulsen S. Pediatric dentistry- A clinical approach. $2^{\text {nd }}$ ed. UK: Wiley-Block Well. 2009. p. 33-47.

5. Blinkhorn GKA. The psychology of dental care. $2^{\text {nd }}$ ed. Oxford: Wright.1991.p. 55-75.

6. Locker D, Liddell A, Dempster LDS. Age of onset of dental anxiety. J Dent Research. 1999;7(9):1-6.

7. Levin GRSL. Self-Assesed dental status, oral behavior, dmf, and dental anxiety. J Dent Educ. 2005;13(8):5-9.

8. Sutadi H. Rasa takut/cemas terhadap perawatan gigl (Laporan perawatan). 1992.

9. Kleinknecht RA, Klepac RK, Alexander LD. Origins and Characteristic of Fear of Dentistry. JADA. 1973;86(1):842-8.

10. Klingberg G, Broberg AG. Temperament and child dental fear. American Academy of Pediatric Dentistry. 1998;20(4):237-43. 